\title{
The Jalur Tikus (Rat Path) Transportation as an Illegal Activity in the Villages of the North Kalimantan Border
}

\author{
Nugroho Trisnu Brata ${ }^{1 *}$ \\ ${ }^{I}$ Department of Sociology \& Anthropology, Faculty of Social Sciences, Universitas Negeri Semarang \\ "Corresponding author. Email : trisnu_ntb2015@mail.unnes.ac.id
}

\begin{abstract}
The state border area is a transitional area between two regions which are different in the law and society. This paper is a study of an illegal transportation, commonly called the jalur tikus (English: rat path) on the Indonesian--Malaysia Border. This study aims to: 1) describe how the form of the rat path illegal transportation in the border area, and 2) understand why such illegal transportation can continue even if it is contrary to the national law. Qualitative method was used as the research method, and the data collecting was done through observation, interview, and news study in the media. The field research was conducted in Nunukan Regency, North Kalimantan Province. The research results indicates that there are three types of rat path, namely the landline, the river path, and the coastal path. Each of those rat path has its own character, although they also have similarity. In summary, this illegal activity is a manifestation of the socioeconomic dynamics of the people in border areas, especially in the border of North Kalimantan with Malaysia. In spite of violating the law, the rat path traffic activities, which transport people and goods, keep going since there are many parties who need and get benefits from the presence of the rat path.
\end{abstract}

Keywords: border area, goods traffic, human traffic, jalur tikus (rat path), socioeconomic dynamics.

\section{INTRODUCTION}

In studies about national borders, researchers usually focus on defense and security issues, border points in the form of stakes that sometimes shift, smuggling of goods, border crossing traffic, border gate activities, education and health services at the border, or illegal traffic lanes.

The border area is a transitional area between two regions whose law and society are different, and also different from the non-border areas. This article tries to discuss the illegal traffic lane at the border which is commonly referred to as the rat path. The rat path or rat road is a term that means a small road, or a road that is unusually passed by public transportation. It can also mean unofficial or illegal roads. A rat path is usually known by the surrounding community. This lane is usually passed by drivers to avoid security forces who are conducting surveillance or raids, traffic jams, or long roads. This paper focuses on the illegal transportation activities on the Indonesia-Malaysia border. This study aims to: 1) describe what kind of the illegal transportation in the border area is, and 2) understand why this illegal transportation can continue even if it is contrary to the state law.

\section{RESEARCH METHOD}

This research used the qualitative method; the data collection was done by observation, interviews, and media news studies. The research was carried out in Nunukan Regency, North Kalimantan Province. In this research, the triangulation technique was used to maintain the data validity, and the qualitative descriptive technique was used the data analysis.

\section{RESULTS AND DISCUSSION}

\subsection{Description of the Area}

The North Kalimantan Province was officially formed since the Law No. 12 of 2012 on 16 November 2012 was signed by the former President of Indonesia, Susilo Bambang Yudhoyono. The province was inaugurated on 22 April 2013, and a new hope arose for 
a better change to the condition. The establishment of North Kalimantan Province, which is a division of the East Kalimantan Province, was actually a basic capital to advance the development for the sectors of economy, education, health, and others in the border regions of the Republic of Indonesia which are directly adjacent to the territory of Malaysia. The area of North Kalimantan Province consists of four regencies and one city, namely: Nunukan Regency, Bulungan Regency, Malinau Regency, Tana Tidung Regency, and Tarakan City. The Governor Office of North Kalimantan is located in Tanjung Selor, Bulungan Regency [1]. The North Kalimantan border region deserves attention in the dynamics of the implemented development in order to be more advanced than before.

The main key to the paradigm shift regarding border areas was started by the awareness of the role of the border region. The condition of the border, which initially was only a form of lines in a map or the political border signs (security check points, passport control and transit points), then progressed to a border dimension so that the borderless nuances are increasingly visible. This phenomenon is seen in European Union countries. This paradigm shift encourages the development of aspects of prosperity so that the function of the border region becomes important as one of the engines of economic growth (strategic areas) even though it is often located in suburbs [2]. Thus, the development of the NKRI (Unitary State of the Republic of Indonesia) borders should be carried out so that the border areas grow into prosperous centers by removing the backward conditions as happened in the NKRI border regions in general [1]. On the northern Kalimantan border, there is a rat path which happens to be the traffic of illegal goods and people, however, deserves attention in the dynamical context of the development of an area.

According to Kompas newspaper [3] which reported, "Energy supply for the Indonesian border communities is still difficult. Some of oil fuel in the North Kalimantan - Malaysia border still comes from Malaysia." While Kompas [4] reported, "The Head (Camat) of Krayan District, Helmi Pudaslikar, said that Indonesia's Independence Day was celebrated on a large scale. Nevertheless, the presence of the state was still lacking in Krayan. Krayan is the NKRI's foremost fortress in North Borneo. It cannot be denied that the feeling of love towards Indonesia is threatened to be eroded if it turns out the welfare in the neighboring country is better". That is a dilemma in the community development at the border which is far from the center of government and economy of the Republic of Indonesia, yet close to the center of economy of the neighboring country. The rat path traffic connecting the regions of Indonesia and Malaysia emerges and colors the dynamics of development at the border.
There are three types of the rat path, namely: land route, river path, and coastal lines; they also have their own characteristics, although they have similarities too. The land route is in the Sungai Limau Village, the river path is in Aji Kuning Village, and the coastal lines are in Sei Pancang Village and Sei Nyamuk Village. In addition to the rat path, there is a port for speed boats in Sei Nyamuk Village that connects Sebatik Island with Tarakan City and Bunyu Island. Previously, at the Sei Nyamuk port there was an immigration office that served speed boat cruises to Tawau Malaysia. On the next trip, the Malaysian immigration service only served legal trips from Tunon Taka Port in Nunukan City, therefore, the immigration service at the Sei Nyamuk port was closed.

\subsection{Rat Path on the Land (Land Route)}

The land routes rat path found in Sungai Limau Village is located on a plateau with hilly and tortuous land contours. This path can only be passed by a motorcycle or by walking. According to Sarkawi (name disguised), an informant, there are four land routes that are usually traversed by residents to cross the border. Other informants, Mr. Daning and Mrs. Hana (both names are disguised), routinely cross the border on this lane. They are migrant workers, a married couple with a child who lives in a house in an oil palm plantation in Bergosong Kecil Village, Sebatik Malaysia. They come from South Sulawesi. Mr. Daning works as a private worker of the oil palm plantation or individual which in Malaysian language is called estate syarikat.

People who work in an individual oil palm plantation (estate syarikat) usually work illegally, that is, they do not have a passport and do not have the license to work abroad. They have the risk of being arrested by Royal Malaysia Polices as illegal workers. Mr. Daning usually crosses the rat path to shop for the necessities in Sebatik Indonesia, he also drives and fetches Mrs. Hana, who works as a teacher at Darul Furqon Islamic Primary School, a border school in Sungai Limau village. From their house at the palm plantation, to a place for shopping for the necessities in Sungai Limau, it takes 30 minutes by motorcycle and it will take longer by walking.

There are also migrant workers who work as laborers of an oil palm plantation owned by a company, which in Malaysian language is called estate company. There are two well-known oil palm plantation companies in Sebatik, Malaysia: Bergosong Estate and Sime Derby Estate. These migrant workers work legally, that is, they have passports and licenses to work in Malaysia. The legal migrant workers live in a kongsi (a tenement/longhouse /block), provided by the plantation company (estate company) for free. They usually cross the rat path to shop for their family life needs to the territory of Indonesia in about 2 to 3 hours by riding a motorcycle in one way. The children of migrant workers in a Malaysia's palm oil plantation do 
not get educational facilities on the plantations so they also have to cross the rat path to go to a school in Indonesia, that is, a border school called Darul Furqon Islamic Primary School. Aril, a child of Mr. Cang, who lives in the Bergosong Dua kongsi, and Vivin, a child of Mr. Iwan, who lives in the Bergosong Besar kongsi, also cross the rat path to go to the Border School. This rat path is in the middle of the Malaysia - Indonesia palm oil plantation.

The region of Sebatik Malaysia is almost entirely in the form of privately-owned or company-owned oil palm plantations. There are almost no centers for shopping for necessities of life. The center of the crowd is in Tawau City, Malaysia across the strait. In Sebatik Malaysia there is only one palm oil processing factory owned by Tek Wan, while in Tawau City there are several palm oil processing factories. Palm oil yields from plantations in Sebatik Malaysia and Sebatik Indonesia are mostly sent to palm oil processing factories in Tawau Malaysia.

\subsection{Rat Path on the River (River Path)}

The river path rat lane is found in Aji Kuning River in Aji Kuning villages which empties into the sea. This small pier is located in an inland protected by large lush trees so it is not visible from afar. The river path can only be traversed by small boats that can carry the life necessities of the community such as nine basic food items, LPG, food and beverage packaging, as well as clothes imported from Tawau Malaysia. Meanwhile, crops products from Sebatik Indonesia such as bananas, durian, cocoa, and lemongrass leaves are sold by middlemen to Tawau through this river path. These middlemen hunt for crops to farmers in Sebatik Indonesia, after the crops commodity is collected, and then transported to Tawau. The commodity trading tool between countries can be in Rupiah or by Ringgit. Shopping in stores, markets, or restaurants can also pay in Rupiah or Ringgit.

The other river path rat lane is on the Lalesalo River, and here are two small piers to accommodate the load of palm oil on to a boat larger than the boat on the Aji Kuning River. The Lalesalo River is wider and deeper so that a rather large boat can enter and dock on two different locations. Palm oil is the main commodity of the crops of Sebatik Indonesia which are sold to Tawau Malaysia. In Tawau, there are a number of palm oil processing factories which can accommodate oil palm harvests from the plantations in Malaysia and from Indonesia. The oil palm fresh fruit bunches are processed into raw materials in the form of CPO (crude palm oil) and kernels (palm seeds). These raw materials can be processed into various derivatives such as biodiesel, cooking oil, butter, cosmetics, and others. Apart from oil palm, the cylinders containing LPG produced in Malaysia are usually unloaded and loaded in this Lalesalo River.

\subsection{Rat Path on the Coast (Coastal Lines)}

The rat path on the coast are located in Sei Pancang Village and Sei Nyamuk Village. The rat lane in Sei Pancang is a small pier that used to be a sawmill from large trees in the Sebatik forest. For several years the sawmill activity has stopped since the forest in Sebatik has run out, and there are no big trees to cut down. The local community call this formerly-sawmill pier Somel (sawmill). This rat lane in Sei Pancang is used to send illegal migrant workers to the region of Sabah Malaysia, which is usually done before the dawn call to prayer around 3 a.m. to 4 a.m. Central Indonesia Time.

Another coastal line rat lane is also found in Sei Nyamuk. In this place there used to be a speedboat port, equipped with a cross-border sea service and an immigration office. However, the service facility was then closed and merged with the same service in Tunon Taka Port, Nunukan City. The Sei Nyamuk domestic speedboat port is still running along with the SebatikTarakan and Sebatik-Bunyu lines. Sei Nyamuk is also the starting point for illegal migrants to come to the region of Sabah Malaysia. As in Sei Pancang, the speedboats that send migrant workers to Malaysia usually leave before the dawn call to prayer around 3 a.m. to 4 a.m. Central Indonesia Time

\subsection{Analysis}

The original communities of Sebatik are the Tidung and the Dayak Lundayeh. The migrant residents generally come from South Sulawesi, Java, and East Nusa Tenggara. The people from South Sulawesi and Java not only live in Sebatik Island, but they also live in the villages along the east coast of Sabah Malaysia, starting from Tawau, Semporna, Lahat Datu, and so on. Those who live in Malaysia and Indonesia maintain a network of family and friends. This network is then used in carrying out activities of transportation and trade between countries, illegally.

The kinship and friendship network between the people becomes a social capital for the transportation and trade activities through the rat lanes at the Malaysia - Indonesia border in North Kalimantan. On one hand, the state is disadvantaged since there is a law violated, and economic losses because there is no inter-state trade tax or merchandise excise received by the state treasury. However, on the other hand, the country also benefits from an increase in the economy and the welfare of the people in the border areas without state interference. The community benefits from being able to minimize transportation time, and minimize costs compared to the official route in Nunukan City, either through Tunon Taka Port or Nunukan Airport. If life necessities or goods are shipped from the center of the Indonesian economy, from Makassar or Surabaya, then it takes about two to five days, and higher costs. 
Two border areas that need each other, and the position of the immigration office and the customs office in Nunukan City which are quite far from the traffic points of land, sea, and river on Sebatik Island, are the main factors for the illegal activities keep moving through the rat lanes. Additional costs incurred for the goods export-import and the ship ticket tax, if the routes are via official lanes, also become a supporting factor for the illegal activities through the rat lanes which are more efficient.

In order to cross the border safely, relatively, the speedboat agents advise the passengers to have a passport first, then report to the immigration office in Nunukan City to be recorded and stamped. To go to Nunukan City from Sei Pancang and Sei Nyamuk (Mosquito River), one must take a black-plated taxi at a cost of 50,000 IDR/person, arriving at Bambangan Port, West Sebatik District. From Bambangan, then take a speedboat across to Nunukan Island, at a cost of 25,000 IDR/person. Nunukan City, as the capital of Nunukan Regency, is located in Nunukan Island. If migrant workers depart from Nunukan to Tawau, then they can take a fast boat at a cost of 250,000 IDR, yet theyhave to go through a long inspection to get a license to work abroad. Traveling to Tawau Malaysia takes about two hours. If prospective migrant workers return to Sei Pancang or Sei Nyamuk from Nunukan, then there is no need to go through the inspection to get a license to work abroad. The cost of riding a speedboat is also cheaper, which is 100,000 IDR or $30 \mathrm{RM}$, and traveling by the sea is also faster, which is about 40 minutes. If prospective migrant workers do not have documents, then they have to pay 500,000 IDR or 150 RM to the owner of the speedboat, of course, with a higher risk of being arrested by the Malaysian Police for being illegal workers.

\section{CONCLUSION}

It can be concluded that this kind of illegal activity, the transportation through the rat lanes, is a dynamical manifestation of social-economic of the people in the border areas, especially at the border of North Kalimantan Province with the Sabah State,
Malaysia. Even though the rat lane traffic violates the law, however, the traffic activities of humans and goods keep moving because many parties need and feel benefited by the existence of the rat lanes.

Indeed, the issues of defense and security in the border areas should not be the first priority in this peaceful condition. The main concern should be on the economic and socio-cultural aspects since theseaspects will influence other aspects. The stomach and happiness matters of the border community have to be fulfilled first, and then the issues of defense and security are addressed next. The rat lane is one of the elements that can prosper the border residents even though it is an illegal activity.

\section{ACKNOWLEDGMENTS}

Researcher(s) would like to thank Universitas Negeri Semarang (State University of Semarang or UNNES) for sponsoring us through the skim of DIPA UNNES (UNNES' Budget Implementation Entry List) of 2020 so that this research has been able to be completed.

\section{REFERENCES}

[1] Brata, N.T. 2020. Authority and Budget for Education Services in the Border

Area: Case Study in Sebatik Island, North Kalimantan in Journal of Forum Ilmu Sosial, 47 (1), June 2020, pp. 19-27. ISSN 1412-971X (print), ISSN 2549-0745 (online). DOI: https://doi.org/10.15294/fis.v47i1. 24269

[2] Muta'ali et al., 2014. Pengelolaan Wilayah Perbatasan NKRI. Yogyakarta: Gadjah Mada University Press.

[3] Kompas (24-10-2016,hal.19). Warga Perbatasan Sulit Akses Energi,

Infrastruktur Sangat Memengaruhi.

[4] Kompas (16-8-2016,hal.35). Mudik Bersama Demi Marayakan 17 Agustus. 